\title{
PENGARUH MEDIA TANAM DAN KONSENTRASI PUPUK ORGANIK CAIR TERHADAP PERTUMBUHAN DAN PRODUKSI TANAMAN SELADA MERAH (Lactuca sativa $\mathrm{L}$. )
}

\author{
Influence of Plant Media and Liquid Organic Fertilizer Concentration on Growth and Production \\ of Red Lettuce (Lactuca sativa L.)
}

\author{
Karim Lamawulo ${ }^{1}$, Herman Rehatta ${ }^{2, *}$, dan Jane I. Nendissa ${ }^{2}$ \\ ${ }^{1}$ Program Studi Agroteknologi, Jurusan Budidaya Pertanian, Fakultas Pertanian, Universitas Pattimura \\ ${ }^{2}$ Jurusan Budidaya Pertanian, Fakultas Pertanian, Universitas Pattimura \\ Jl. Ir. M. Putuhena, Kampus Poka Ambon, 97233 \\ *Penulis Korespondensi: e-mail: hermanrehatta@gmail.com
}

\begin{abstract}
Planting media and concentration of liquid organic fertilizer were the main components that play a role as a medium to grow plants and nutrients supply for the red lettuce. To obtain appropriate planting medium and concentration of liquid organic fertilizer for growth and production of red lettuce plant, an experiment was conducted using Randomized Block Design Factorial, i.e Liquid Organic Fertilizer concentration with 6 treatment level, KO (Without Treatment), K1 (POC $5 \mathrm{cc} / \mathrm{L})($ POC $20 \mathrm{cc} / \mathrm{L}), \mathrm{K} 4$ (POC $20 \mathrm{cc} / \mathrm{L})$ and K5 (POC $25 \mathrm{cc} / \mathrm{L})$ and Planting Media with 3 levels i.e, M1 (3:1), M2 (4:1) and M3 (5:1). The concentration of liquid organic fertilizer gave very significant effects to the height parameters of plant (cm), number of leaves (leaf), leaf area $\left(\mathrm{cm}^{2}\right)$, fresh weight of crown $(\mathrm{g})$ and fresh root weight $(\mathrm{g})$. Planting media had very significant effects on fresh root weight $(\mathrm{g})$, ratio of root and canopy (\%) and harvest index (\%).
\end{abstract}

Keywords: growth, organic fertilizer, planting media, production, red lettuce

\begin{abstract}
ABSTRAK
Media tanam dan konsentrasi pupuk organik cair merupakan komponen utama yang memiliki peranan sebagai tempat tumbuh tanaman dan penyedia unsur hara bagi kebutuhan tanaman selada merah. Untuk memperoleh media tanam dan konsentrasi pupuk organik cair yang tepat bagi pertumbuhan dan produksi tanaman selada merah dilakukan percobaan dengan menggunakan Rancangan Acak Kelompok faktorial diantaranya, Konsentrasi Pupuk Organik Cair dengan 6 taraf perlakuan yaitu, K0 (Tanpa Perlakuan), K1 (POC 5 cc/L), K2 (POC 10 cc/L), K3 (POC 15 cc/L), K4 (POC 20 cc/L) dan K5 (POC 25 cc/L) dan Media Tanam dengan tiga taraf yaitu, M1 (3:1), M2 (4:1) dan M3 (5:1). Konsentrasi pupuk organik cair memberikan pengaruh sangat nyata terhadap parameter tinggi tanaman $(\mathrm{cm})$, jumlah daun (helai), luas daun $\left(\mathrm{cm}^{2}\right)$, berat segar tajuk $(\mathrm{g})$ dan berat segar akar $(\mathrm{g})$. Media tanam memberikan pengaruh sangat nyata terhadap parameter berat segar akar (g) rasio tajuk akar $(\%)$ dan indeks panen $(\%)$.
\end{abstract}

Kata kunci: media tanam, pertumbuhan, produksi, pupuk organik, selada merah

\section{PENDAHULUAN}

Selada merah (Lactuca sativa L.) merupakan tanaman hortikultura penting yang dimanfaatkan sebagai salah satu pelengkap makanan pokok dan sebagai sumber vitamin serta mineral. Pengembangan selada merah mempunyai prospek yang baik untuk mendukung upaya peningkatan gizi masyarakat dan pendapatan petani. Oleh karena itu, tanaman selada merah sangat penting untuk diusahakan dalam usaha pertanian.

Untuk memenuhi kebutuhan konsumsi selada merah yang semakin besar, diperlukan penanganan pembudidayaan yang serius melalui usaha intensifikasi (peningkatan produksi) dan usaha ekstensifikasi (perluasan areal pertanaman). Peningkatan produksi melalui usaha intensifikasi pertanian meliputi kegiatan cara bercocok tanam, penggunaan varietas unggul, pemupukan, pengairan, dan pengendalian hama serta penyakit tanaman. Sedangkan peningkatan produksi melalui usaha ekstensifikasi pertanian adalah memperluas areal lahan penanaman (Sa'diah, 2015).

Upaya penggunaan media tanam yang baik dalam pengembangan tanaman selada merah sangat diperlukan untuk meningkatkan hasil produksi tanaman. Media tanam merupakan komponen utama yang dibutuhkan dalam budidaya tanaman. Media tanam banyak macam ragamnya, dapat merupakan campuran dari bermacammacam bahan atau satu jenis bahan saja asalkan memenuhi beberapa persyaratan, antara lain cukup baik dalam memegang air, bersifat porous sehingga air 
siraman tidak menggenang (becek), tidak bersifat toksik (racun) bagi tanaman, dan yang paling penting media tanam tersebut cukup mengandung unsur-unsur hara yang diperlukan bagi pertumbuhan tanaman (Widarto, 1996).

Untuk mendapatkan media tanam yang sesuai diperlukan langkah kombinasi salah satu jenis tanah yang cocok untuk pertumbuhan tanaman selada dengan pupuk kandang. Salah satu kombinasinya adalah dengan menggunakan jenis tanah regosol dan pupuk kandang ayam. Tanah regosol sendiri merupakan salah satu jenis tanah yang mengandung bahan induk aluvial (Luhukay, 2017). Pupuk kandang ayam yang digunakan sangat baik untuk tanaman karena banyak mengandung zat-zat makanan tanaman karena susunan makanannya banyak mengandung protein serta mengandung nitrogen 3 kali lebih banyak dari pupuk kandang lainnya. Pupuk ini lebih cepat bereaksi didalam tanah karena termasuk pupuk panas (Musnamar, 2003).

Salah satu usaha yang dilakukan untuk meningkatkan kualitas tanaman adalah dengan penambahan pupuk organik cair yang dapat memperbaiki sifat fisik, kimia, dan biologi tanah, membantu meningkatkan produksi tanaman, meningkatkan kualitas tanaman seperti protein kasar dan dapat mengurangi penggunaan pupuk anorganik (Indrakusuma 2000). Menurut Rizqiani et al. (2007) penggunaan pupuk organik cair juga dapat memperbaiki struktur tanah sehingga menjadi gembur dan akar tanaman lebih mudah menembus tanah dan menyerap unsur hara serta memperbaiki pertumbuhan, mempercepat panen, memperpanjang masa atau umur produksi dan dapat meningkatkan hasil tanaman.

Salah satu dari sekian pupuk organik cair adalah pupuk organik cair Bioliz. Pupuk ini dibuat dari limbah pertanian seperti daun Gamal, Kulit Pisang, larutan biakan Mikroorganisme PGR, larutan Ekstrak Rumput Laut dan Gula Merah (Kaya dan Siregar 2016). Saat ini pupuk organik cair bioliz belum banyak digunakan dalam proses budidaya tanaman. Hal ini dikarenakan produksi pupuk organik cair ini tersebut tergolong baru dan masih dalam tahap penelitian untuk mendapatkan kensentrasi yang optimum dalam menunjang peningkatan produktivitas tanaman.

\section{METODOLOGI PENELITIAN}

Penelitian ini dilaksanakan di Ruamah Kaca Fakultas Pertanian Universitas Pattimura pada bulan Oktober sampai Desember 2016. Peralatan yang digunakan dalam penelitian ini adalah Parang, Sekop, Ayakan, Palu, Gergaji, Hiter, Sprayer, Meteran, Neraca, Oven, Timbangan Analitic, Kamera, Spidol, Gelas Ukur dan Alat Tulis. Bahan yang digunakan yaitu Selada Merah varitas Red Rapid, Pupuk organik cair Bioliz, Pupuk Kandang Ayam, Media Tanah, Pestisida Nabati, Kayu, Paku, Karung, Amplop, Paku Pompa, Karton, Gelas Aqua dan Polybag $10 \mathrm{~cm}$ dan Polybag diameter 30 $\mathrm{cm}$.

\section{Desain Penelitian}

Penelitian ini dilaksanakan dengan bentuk percobaan dua faktor dalam rancangan acak kelompok. Faktor pertama adalah pemberian pupuk organik cair (K) dengan taraf konsentrasi diantaranya sebagai berikut:K0 = Tanpa pemberian pupuk organik cair Bioliz; K1 = Pemberian pupuk organik cair Bioliz konsentrasi $5 \mathrm{cc} / \mathrm{L}$ air; K2 = Pemberian pupuk organik cair Bioliz konsentrasi $10 \mathrm{cc} / \mathrm{L}$ air; K3 = Pemberian pupuk organik cair Bioliz konsentrasi $15 \mathrm{cc} / \mathrm{L}$ air; $\mathrm{K} 4=$ Pemberian pupuk organik cair Bioliz konsentrasi $20 \mathrm{cc} / \mathrm{L}$ air; K5 = Pemberian pupuk organik cair Bioliz konsentrasi $25 \mathrm{cc} / \mathrm{L}$ air. Faktor kedua adalah pengaruh media tanam (M) dengan perbandingan diantaranya sebagai berikut:M1 = Perbandingan 3 tanah / 1 pupuk kandang; M2 = Perbandingan 4 tanah / 1 pupuk kandang; danM3 = Perbandingan 5 tanah / 1 pupuk kandang.

\section{Prosedur Penelitian}

\section{Persiapan Rumah Kaca dan Media Tanam (Media Semai)}

Persiapan Rumah Kaca adalah langkah awal untuk memulai penelitian ini dengan melakukan pembersihan dari sampah dan hal-hal lainnya yang dianggap dapat menggangu pelaksanaan penelitian. Setelah dilakukan pembersihan rumah kaca, selanjutnya melakukan penyiapan media semai yaitu campuran tanah dengan pupuk kandang ayam pada perbandingan $3: 1$ dan dimasukan kedalam polybag berukuran $15 \mathrm{~cm}$.

\section{Penyiapan Benih dan Pembibitan}

Benih selada merah yang akan digunakan dalam penelitian ini adalah benih selada merah varitas Red Rapid. Sebelum disemai benih direndam terlebih dahulu dalam air selama \pm 15 menit, lalu ditiriskan (dikeringkan) kembali. Media pesemaian disiram hingga cukup basah atau lembab. Selanjutnya ditanam secara tugal sedalam $2-3 \mathrm{~cm}$ sebanyak 5 benih per lubang kemudian tutup dengan tanah tipis dan halus. Siram permukaan bedengan pesemaian dengan menggunakan sprayer yang berlubang-lubang kecil dan halus. Setelah dilakukan pesemaian benih selada merah dilanjutkan dengan proses pemeliharaan. Bibit dipelihara secara intensif terutama rutin melakukan penyiraman dan pengawasan terhadap serangan hama maupunpenyakit.

\section{Persiapan Media Tanam}

Persiapan media tanam dilakukan 1 minggu sebelum penanaman berlangsung. Media tanah yang digunakan adalah jenis tanah regosol yang diambil pada lapisan top soil. Tanah tersebut selanjutnya diayak untuk memisahkan batu maupun kotoran untuk selanjutnya dicampur dengan pupuk kandang pada perbandingan 3 : 1, 4: 1 dan 5: 1. Media tanam yang telah tercampur sesuai perbandingan selanjutnya dimasukan kedalam wadah polybag berdiameter $30 \mathrm{~cm}$ dengan bobot berat media tanam $5 \mathrm{~kg}$ per wadah. 


\section{Penanaman}

Bibit yang telah berumur $30-35$ hari ditandai dengan adanya 3-5 helai siap untuk dipindahkan dari pesemaian ke media yang telah disiapkan dan selanjutnya disiram hingga media cukup basah. Waktu penanaman dilakukan pada pagi ataupun sore hari. Bibit yang ditanam adalah bibit yang diseleksi biasanya pada bibit yang pertumbuhannya sehat dan seragam serta terdapat 1 bibit tanaman yang akan ditanam dalam setiap wadah. Pengaturan jarak tanam itu sendiri diantaranya adalah jarak antar polybag $10 \mathrm{~cm}$.

\section{Pemberian Pupuk Organik Cair}

Pemberian pupuk organik cair sesuai dengan perlakuan yang akan coba pada penelitian ini dengan konsentrasi perlakuan adalah K0 (Tanpa Pemberian POC Bioliz), K1 (Konsentrasi POC Bioliz 5 cc/L Air), K2 (Konsentrasi POC Bioliz $10 \mathrm{cc} / \mathrm{L}$ Air), K3 (Konsentrasi POC Bioliz $15 \mathrm{cc} / \mathrm{L}$ Air), K4 (Konsentrasi POC Bioliz $20 \mathrm{cc} / \mathrm{L}$ Air) dan K5 (Konsentrasi POC Bioliz $25 \mathrm{cc} / \mathrm{L}$ Air). Volume pemberian adalah $150 \mathrm{cc}$ pada tanaman yang telah berumur 1 Minggu Setelah Tanam (MST) dengan selang waktu pemberian 1 minggu sekali. Pemberian pupuk organik cair pada tahap ini dikarenakan umur 1 MST merupakan waktu yang cukup untuk tanaman menyesuaikan dengan kondisi media tanam serta tanaman sudah dapat merespon unsur hara yang diberikan melalui pemberian pupuk organik cair dan pemberiannya sampai dengan 6 minggu setelah tanam (MST). Cara pemakaiannya adalah dituangkan larutan pupuk organik cair yang telah dicampurkan kedalam masing-masing gelas aqua dengan volume yang ditetapkan kemudian disiramkan langsung ke tanaman.

\section{Pemeriharaan}

Pemeliharaan tanaman setelah ditanam meliputi penyiraman rutin setiap pagi dan sore hari, penyiangan dilakukan apabila ada gulma yang tumbuh diareal pertanaman, penyulaman terhadap tanaman tanaman yang telah mati, serta pengendalian hama dan penyakit dilakukan dengan menggunakan pestisida nabati ekstrak daun sirsak dengan konsentrasi $10 \mathrm{cc} / 1 \mathrm{~L}$ air. Cara pembuatan Pestisida itu sendiri adalah dihaluskan 100 helai daun sirsak selanjutnya dimasukan kedalam jerigen yang berisi $1 \mathrm{~L}$ air ditambah dengan $2 \mathrm{sdm}$ deterjen bubuk dan didiamkan selama 1 malam.

\section{Panen}

Pemanenan tanaman selada merah dilakukan pada saat tanaman memasuki umur 6 SMT. Cara memanen selada adalah dilakukan dengan mencabut seluruh bagian tanaman bersama akar-akarnya atau dengan jalan memotong pangkal batang tanaman diatas tanah.

\section{Variabel Pengamatan}

Pengamatan yang akan dilakukan dalam penelitian ini adalah peubah pertumbuhan dan produksi tanaman selada merah meliputi :

\section{Tinggi Tanaman $(\mathbf{c m})$}

Tinggi tanaman akan diketahui dengan cara mengukur tinggi tanaman sampel dari pangkal batang sampai pada titik tertinggi tanaman. Pengukuran dilakukan 1 minggu sekali dimulai dari tanaman berumur 1 minggu setelah pemberian pupuk organik cair sampai dengan waktu panen.

\section{Jumlah Daun (Helai)}

Jumlah daun dihitung pada semua daun yang telah terbuka sempurna dan pengamatan dilakukan setiap 1 minggu sekali saat tanaman berumur 1 minggu setelah pemberian pupuk organik cair sampai dengan waktu panen.

\section{Luas Daun (cm)}

Luas daun ukur setelah tanaman mencapai masa panen (6 MST). Pengukuran dilakukan terhadap 3 helai daun yang diambil sebagai sampel (atas, tengah dan bawah) yang dikeringkan dengan menggunakan oven selama 24 jam dengan suhu $70{ }^{\circ} \mathrm{C}$ selanjutnya ditimbang dan kemudian dirata-ratakan. Pengukuran luas daun menggunakan rumus Sitompul dan Guritno (1995):

$\mathrm{LD}=\left(\mathrm{W}_{\mathrm{r}} / \mathrm{W}_{\mathrm{t}}\right) \times(\mathrm{LK})$

Dimana: LD $=$ Luas Daun $\left(\mathrm{cm}^{2}\right) ; \mathrm{W}_{\mathrm{r}}=$ Bobot kertas replika daun $(\mathrm{g}) ; \mathrm{W}_{\mathrm{t}}=$ Bobot kertas total $(\mathrm{g}) ; \mathrm{LK}=$ Luas kertas standar $\left(\mathrm{cm}^{2}\right)$.

\section{Berat Segar Tajuk (g)}

Berat segar tanaman selada merah dapat diamati pada saat masa panen yaitu 6 MST dimana tanaman selada yang dipanen dipotong pada pangkal batang untuk memisahkan dengan akar dan selanjutnya ditimbang menggunakan timbangan/Neraca.

\section{Berat Segar Akar (g)}

Pengamatan bobot segar akar dilakukan pada saat masa panen yaitu tanaman berumur 6 MST selanjutnya ditimbang akar tanaman tersebut yang dipisahkan dari tajuk (Memotong) dengan menggunakan Neraca.

\section{Rasio Tajuk Akar (\%).}

Pengamatan rasio tajuk akar merupakan perbandingan antara berat segar tajuk dan segar akar tanaman yang ditimbang terlebih dahulu lalu di bandingkan. Pengamatan ini dilakukan 6 MST atau pada masa panen. Perhitungan nilai tajuk akar ini dapat diperoleh dengan menggunakan rumus (Sitompul dan Guritno, 1995):

Rasio tajuk akar $=($ Berat segar tajuk tanaman $/$ berat segar akan tanaman) $\times 100 \%$

\section{Indeks Panen (\%).}

Indeks panen (IP) atau Harvest Indeks (HI) yaitu kemampuan tanaman dalam menyalurkan asimilat tanpa satuan. Pengamatan ini dilakukan 6 MST atau pada masa panen dan dihitung dengan menggunakan rumus (Sitompul dan Guritno, 1995).

$$
\mathrm{HI}=(\mathrm{Y} / \mathrm{W}) \times 100 \%
$$


Dimana: $\mathrm{HI}=$ Harvert Indeks; $\mathrm{Y}=$ Hasil Tanaman/Berat Segar Tajuk; W= Berat Segar Total.

\section{Analisis Data}

Analisis data dari peubah yang diamati, dilakukan dengan menggunakan Analisis Varians (ANOVA) dan jika terdapat pengaruh perlakuan yang nyata dan sangat nyata dilanjutkan dengan Uji Duncan pada taraf 0.05. Sedangkan untuk mengetahui hubungan antar peubah yang diamati, akan dilakukan analisis korelasi.

\section{HASIL DAN PEMBAHASAN}

\section{Hasil}

Berdasarkan pada hasil analisis keragaman terdapat pengaruh konsentrasi pupuk organik cair dan media tanam terhadap pertumbuhan dan produksi tanaman selada merah (Lactuca sativa L.) Konsentrasi pupuk organik cair $(\mathrm{K})$ memberikan pengaruh sangat nyata pada parameter tinggi tanaman, jumlah daun dan luas daun serta parameter berat segar tajuk dan berat segar akar. Sedangkan untuk parameter rasio tajuk akar dan indeks panen, konsentrasi pupuk organik cair (K) tidak memberikan pengaruh yang nyata.

Media tanam (M) juga tidak menunjukkan pengaruh yang nyata terhadap beberapa parameter diantaranya adalah parameter tinggi tanaman, jumlah daun, luas daun dan berat segar tajuk tetapi memberikan pengaruh yang sangat nyata terhadap parameter berat segar akar, rasio tajuk akar dan indeks panen. Sedangkan bagian lain pada tabel yaitu interaksi konsentrasi pupuk organik cair (K) dan media tanam (M) tidak memberikan pengaruh yang nyata terhadap semua parameter.

\section{Tinggi Tanaman (cm)}

Hasil analisis keragaman pada Tabel 1 menunjukkan konsentrasi pupuk organik cair (K) berpengaruh sangat nyata terhadap parameter tinggi tanaman Selada Merah pada umur 6 minggu setelah tanam (MST).

Tabel 1. Rata-rata pengaruh konsentrasi pupuk organik cair pada parameter tinggi tanaman $(\mathrm{cm})$

\begin{tabular}{|c|c|}
\hline $\begin{array}{c}\text { Perlakuan (Konsentrasi POC } \\
\text { Bioliz) }\end{array}$ & Rata-Rata \\
\hline K0 (0 cc/L air $)$ & $36,11^{\mathrm{d}}$ \\
\hline K1 (5 cc/L Air) & $40,63^{\mathrm{c}}$ \\
\hline $\mathrm{K} 2$ (10 cc/L Air) & $40,39^{\mathrm{c}}$ \\
\hline K3 (15 cc/L Air) & $41,25^{\mathrm{c}}$ \\
\hline K4 (20 cc/L Air) & $45,69^{b}$ \\
\hline K5 (25 cc/L Air) & $51,92^{\mathrm{a}}$ \\
\hline Duncan $0,05: 3,49 \quad 3,67 \quad 3,78$ & 3,93 \\
\hline
\end{tabular}

Keterangan: Angka-angka yang diikuti huruf yang sama, tidak berbeda nyata pada taraf uji beda Duncan 0,05 .
Berdasarkan hasil Uji Beda Duncan 0,05 pada Tabel 1 menghasilkan nilai rata-rata parameter tinggi tanaman selada merah tertinggi diperoleh pada perlakuan K5 setinggi 51,92 $\mathrm{cm}$ dan berbeda sangat nyata dengan perlakuan lainnya. Pada perlakuan K4 memperoleh nilai tertinggi kedua dengan tinggi tanaman $45,69 \mathrm{~cm}$ dan juga berbeda sangat nyata dengan perlakuan lainnya. Perlakuan K3 memiliki tinggi tanaman $41,25 \mathrm{~cm}$ dan tidak berbeda nyata dengan perlakuan $\mathrm{K} 2$ dengan tinggi tanaman 40,39 cm dan K1 dengan tinggi tanaman 40,63 $\mathrm{cm}$ tetapi berbeda sangat nyata dengan $\mathrm{K} 0$ dengan tinggi tanaman paling rendah yaitu dengan tinggi $36,11 \mathrm{~cm}$. Perentase peningkatan tinggi tanaman terhadap pemberian pupuk organik cair adalah sebesar $43,78 \%$.

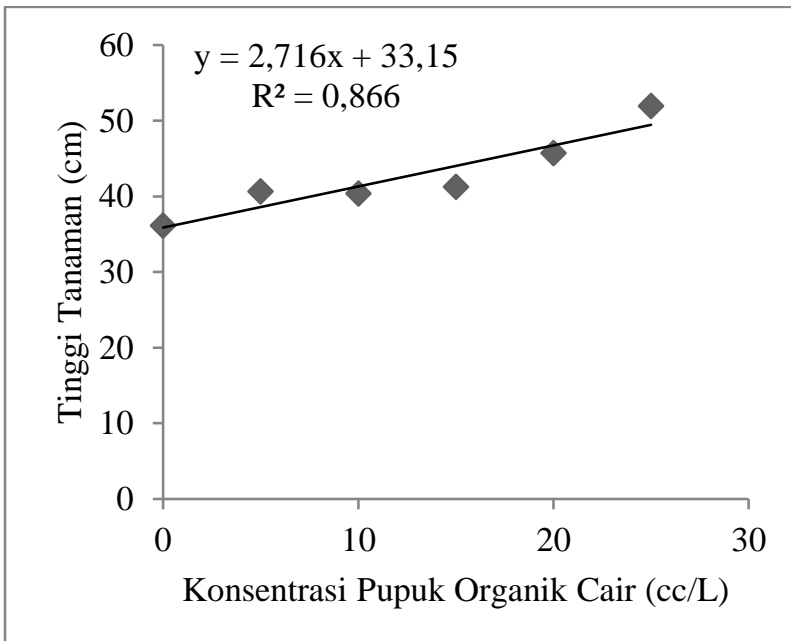

Gambar 1. Grafik analisis regresi rata-rata nilai konsentrasi pupuk organik cair (k) Pada parameter tinggi tanaman selada merah

Tabel 2. Rata-rata pengaruh konsentrasi pupuk organik cair pada parameter jumlah daun (helai)

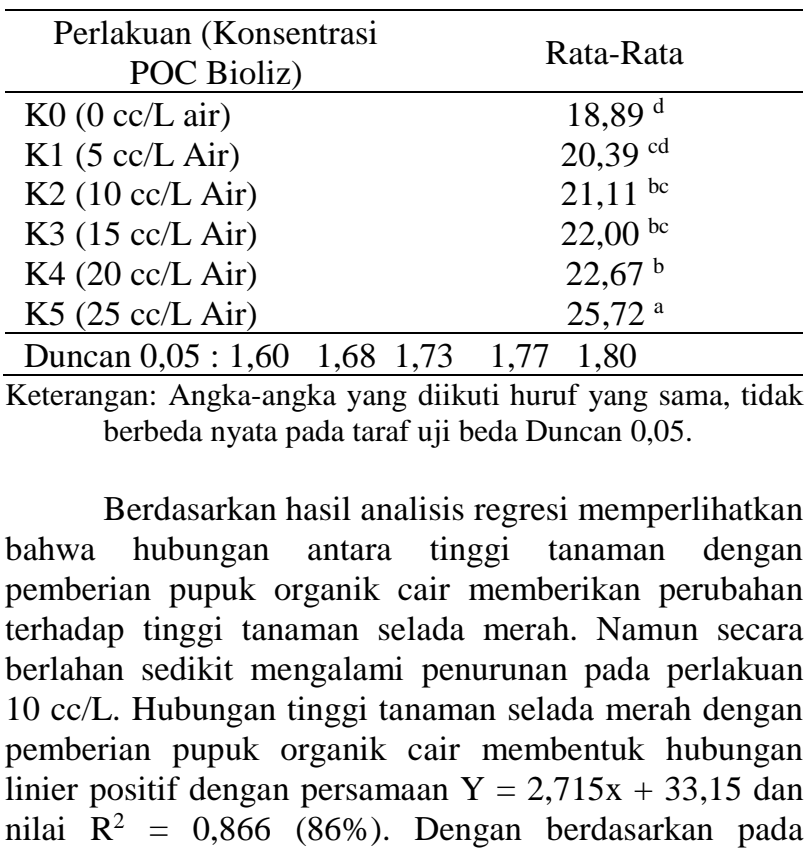


Gambar 1 tersebut menunjukkan bahwa jika ada penambahan perlakuan diduga akan meningkatkan tinggi tanaman selada merah.

\section{Jumlah Daun (Helai)}

Hasil analisis keragaman pada tabel 2 menunjukan konsentrasi pupuk organik cair (K) berpengaruh sangat nyata terhadap parameter jumlah daun selada merah pada umur 6 minggu setelah tanam (MST).

Berdasarkan hasil uji beda duncan 0,05 pada tabel 2 menghasilkan nilai rata-rata parameter jumlah daun selada merah terbanyak jatuh pada perlakuan K5 yaitu sebanyak 25,72 helai dan berbeda sangat nyata dengan perlakuan lainnya. Pada perlakuan K4 memperoleh nilai terbanyak kedua dengan jumlah daun sebanyak 22,67 helai dan juga berbeda nyata dengan perlakuan $\mathrm{K} 3$ dan $\mathrm{K} 2$ serta berbeda sangat nyata dengan perlakuan K1 dan K0. Sedangkan pada perlakuan K3 memperoleh jumlah daun sebanyak 22.00 helai dan tidak berbeda nyata dengan perlakuan $\mathrm{K} 2$ yang memperoleh jumlah daun sebanyak 21,11 helai tetapi berbeda nyata dengan K1 serta berbeda sangat nyata dengan perlakuan K0. Pada perlakuan K1 memperleh jumlah dan sebanyak 20,39 helai dan berbeda nyata dengan perlakuan perlakuan K0 yang memperoleh jumlah daun sebanyak 18,89 helai. Pada pertambahan jumlah daun terhadap pemberian pupuk organik cair Presentae peningkatannya adalah sebasar $36,16 \%$.

Berdasarkan hasil analisis regresi memperlihatkan hubungan jumlah daun selada merah dengan pemberian pupuk organik cair dengan persamaan $\mathrm{Y}=1,198 \mathrm{x}+$ 17,60 dengan koefisien determinasi $\left(\mathrm{R}^{2}=0,924\right) 98 \%$ tersebut menggambarkan adanya hubungan linear positif antara jumlah daun dan pemberian pupuk organik cair. Dengan nilai regreasi $\mathrm{R}^{2}=0,924$ menunjukkan hubungan antar perlakuan semakin erat dan jumlah daun selada merah diduga akan bertambah seiring dengan pertambahan perlakuan dosis pupuk organik cair.

\section{Luas Daun $\left(\mathrm{cm}^{2}\right)$}

Hasil analisis keragaman pada tabel 3 menunjukkan konsentrasi pupuk organik cair (K) berpengaruh sangat nyata terhadap parameter luas daun selada merah pada umur 6 minggu setelah tanam (MST).

Berdasarkan hasil uji beda duncan 0,05 pada tabel 3 menghasilkan nilai rata-rata parameter luas daun selada merah terluas jatuh pada perlakuan K5 dengan luas $216,12 \mathrm{~cm}^{2}$ dan berbeda sangat nyata dengan perlakuan lainnya. Perlakuan K4 merupakan yang terluas kedua dengan luas daun $190,56 \mathrm{~cm}^{2}$ dan berbeda nyata dengan perlakuan K3 serta berbeda sanyat nyata dengan perlakuan lainnya. Pada perlakuan K3 memiliki luas daun $176,32 \mathrm{~cm}^{2}$ dan berbeda nyata dengan perlakuan $\mathrm{K} 2$ serta juga berbeda sangat nyata dengan perlakuan lainnya. Perlakuan K2 memiliki luas dauan 172,00 cm dan berbedanyata dengan perlakuan $\mathrm{K} 1$ serta berbeda sangat nyata dengan perlakuan K0. Pada perlakuan K1 memiliki luas daun $158,58 \mathrm{~cm}^{2}$ dan berbeda nyata dengan K0 dengan luas daun terendah dengan luas $151,64 \mathrm{~cm}^{2}$. Presentase peningkatan luas daun terhadap pemberian pupuk organik cair adalah sebasar $42,52 \%$.

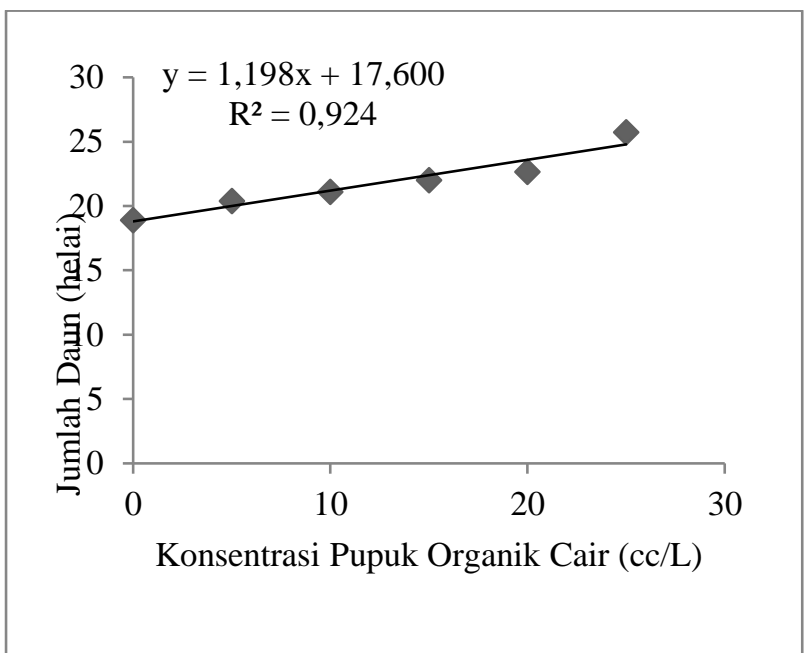

Gambar 2. Grafik analisis regresi rata-rata nilai konsentrasi pupuk organik cair (k) pada parameter jumlah daun selada merah

Tabel 3. Rata-rata pengaruh konsentrasi pupuk organik cair pada parameter luas daun $\left(\mathrm{cm}^{2}\right)$

\begin{tabular}{|c|c|}
\hline $\begin{array}{c}\text { Perlakuan (Konsentrasi } \\
\text { POC Bioliz) }\end{array}$ & Rata-Rata \\
\hline K0 (0 cc/L air $)$ & $151,64^{\mathrm{e}}$ \\
\hline K1 (5 cc/L Air) & $158,58 \mathrm{de}$ \\
\hline K2 (10 cc/L Air) & $172,00^{\mathrm{cd}}$ \\
\hline K3 (15 cc/L Air) & $176,32 \mathrm{bc}$ \\
\hline K4 (20 cc/L Air) & $190,56^{b}$ \\
\hline K5 (25 cc/L Air) & $216,12^{a}$ \\
\hline
\end{tabular}

Keterangan: Angka-angka yang diikuti huruf yang sama, tidak berbeda nyata pada taraf uji beda Duncan 0,05 .

Berdasarkan hasil analisis regresi menunjukkan hubungan luas daun tanaman selada merah dengan pemberian pupuk organik cair mampu meningkatkan laju pertumbuhan luas daun secara signifikan dengan mengikuti persamaan $\mathrm{Y}=12,07 \mathrm{x}+135,2$ dengan nilai $\mathrm{R}^{2}=0,938(93 \%)$. Persamaan tersebut menunjukkan adanya hubungan linear positif antara luas daun dengan pemberian pupuk organik cair dimana membentuk hubungan yang makin erat antar perlakuan sehingga jika ada penambahan perlakuan dosis pupuk organik cair maka dapat diduga akan cenderung meningkatkan laju pertumbuhan luas daun tanaman selada merah.

\section{Berat Segar Tajuk (g)}

Hasil analisis keragaman pada tabel 4 menunjukkan konsentrasi pupuk organik cair (K) berpengaruh sangat nyata terhadap parameter berat segar tajuk selada merah pada umur 6 minggu setelah tanam (MST). 
Berdasarkan hasil uji beda duncan 0,05 pada tabel 4 menghasilkan nilai rata-rata parameter berat segar tajuk selada merah terberat dihasilkan pada perlakuan K5 dengan berat $167,39 \mathrm{~g}$ dan berbeda sangat nyata dengan perlakuan lainnya, Pada perlakuan K3 memiliki berat segar tajuk 153,83 g dan tidak berbeda nyata dengan perlakuan K4 dengan berat $151,11 \mathrm{~g}$, K2 dengan berat 147,22 g, K1 dengan berat 146,94 g dan perlakuan K0 paling terendah dengan berat $141,72 \mathrm{~g}$, Pada parameter ini terdapat peningkatan beratnya terhadap pemberian pupuk organik cair dengan presentase adalah sebasar $18,11 \%$

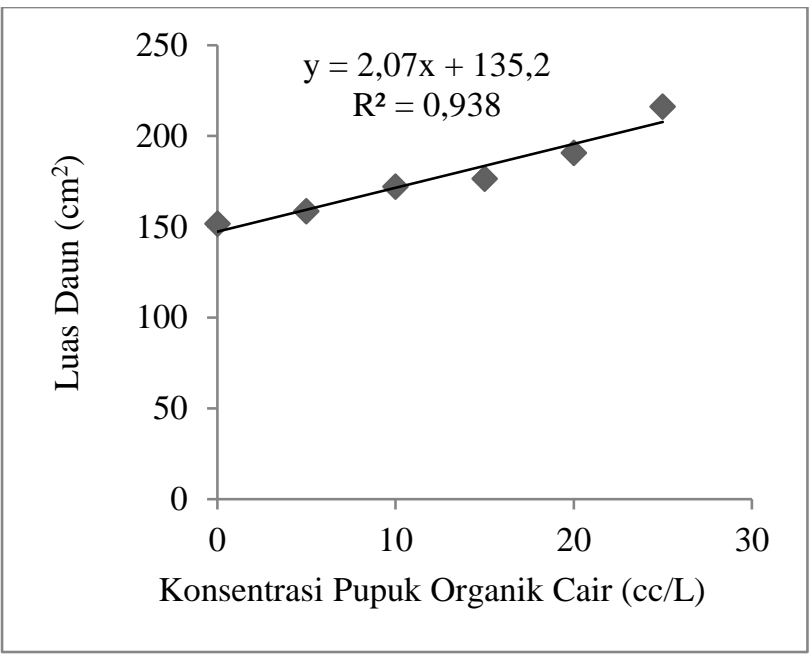

Gambar 3. Grafik analisis regresi rata-rata nilai konsentrasi pupuk organik cair (K) pada parameter luas daun selada merah

Tabel 4. Rata-rata pengaruh konsentrasi pupuk organik cair pada parameter berat segar tajuk $(\mathrm{g})$

\begin{tabular}{lc}
\hline $\begin{array}{c}\text { Perlakuan (Konsentrasi } \\
\text { POC Bioliz) }\end{array}$ & Rata-Rata \\
\hline K0 (0 cc/L air) & $141,72^{\mathrm{b}}$ \\
K1 (5 cc/L Air) & $146,94^{\mathrm{b}}$ \\
K2 (10 cc/L Air) & $147,22^{\mathrm{b}}$ \\
K3 (15 cc/L Air) & $153,83^{\mathrm{b}}$ \\
K4 (20 cc/L Air) & $151,11^{\mathrm{b}}$ \\
K5 (25 cc/L Air) & $167,39^{\mathrm{a}}$ \\
\hline
\end{tabular}

Duncan 0,05 : $11,94 \quad 12,08 \quad 12,46 \quad 12,73 \quad 12,94$

Keterangan: Angka-angka yang diikuti huruf yang sama, tidak berbeda nyata pada taraf uji beda Duncan 0,05

Berdasarkan hasil analisis regresi dapat dilihat bahwa adanya hubungan linear positif antara berat segar tajuk selada merah dengan pemberian pupuk organik cair dengan persamaan $\mathrm{Y}=4,213 \mathrm{x}+136,6$ dengan nilai $\mathrm{R}^{2}=$ 0,791 (79\%) dimana pemberian pupuk organik cair memberikan pengaruh signifikan terhadap berat segar tajuk tanaman selada merah, namun secara berlahan mengalami penurunan berat batas maksimum pada perlakuan $20 \mathrm{cc} / \mathrm{L}$, Dan pada Gambar 4 tersebut juga dapat diduga bahwa berat segar tajuk tanaman selada merah cenderung meningkat jika ada penambahan perlakuan dosis pupuk organik cair.

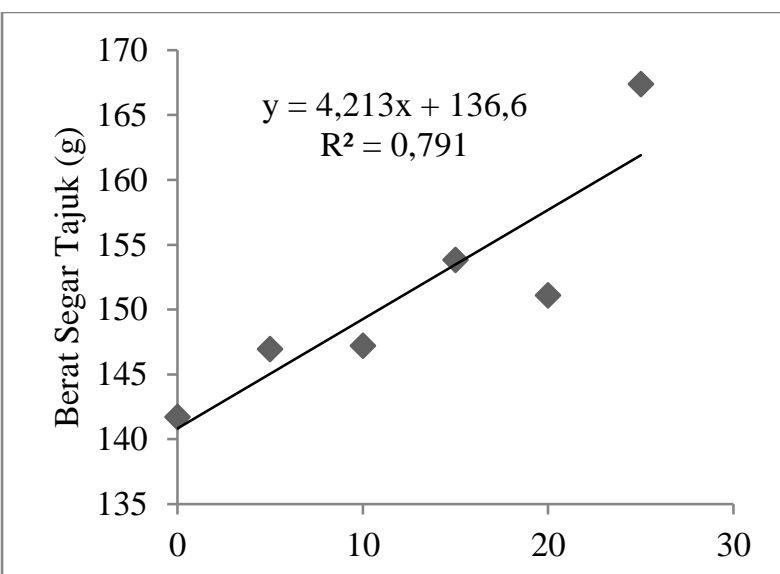

Konsentrasi Pupuk Organik Cair (cc/L)

Gambar 4. Grafik analisis regresi rata-rata nilai konsentrasi pupuk organik cair (K) pada parameter berat segar tajuk selada merah

\section{Berat Segar Akar (g)}

Hasil analisis keragaman pada tabel 5 menunjukan konsentrasi pupuk organik cair (K) berpengaruh sangat nyata terhadap parameter berat segar akar selada merah pada umur 6 minggu setelah tanam (MST).

Berdasarkan hasil uji beda duncan 0,05 pada tabel 5 menghasilkan nilai rata-rata parameter berat segar akar selada merah terberat dihasilkan pada perlakuan K5 dengan berat 19,06 g dan berbeda sangat nyata dengan perlakuan lainnya, Perlakuan K3 merupaka perlakuan terberat kedua dengan berat $16,39 \mathrm{~g}$ dan tidak berbeda nyata dengan perlakuan K4 dengan berat 16,28 g, K2 dengan berat $15,78 \mathrm{~s} \mathrm{g,} \mathrm{K1} \mathrm{dengan} \mathrm{berat} 15,44 \mathrm{~g}$ serta K0 yang merupakan paling rendah dengan berat $15,00 \mathrm{~g}$ dan presentase peningkatan berat akarnya sebesar $27,07 \%$.

Hasil analisis keragaman pada Tabel 6 menunjukkan media tanam (M) berpengaruh sangat nyata terhadap parameter berat segar akar selada merah pada umur 6 minggu setelah tanam (MST).

Tabel 5. Rata-rata pengaruh konsentrasi pupuk organik cair pada parameter berat segar akar $(\mathrm{g})$

\begin{tabular}{lc}
\hline $\begin{array}{c}\text { Perlakuan (Konsentrasi } \\
\text { POC Bioliz) }\end{array}$ & Rata-Rata \\
\hline K0 (0 cc/L air) & $15,00^{\mathrm{b}}$ \\
K1 (5 cc/L Air) & $15,44^{\mathrm{b}}$ \\
K2 (10 cc/L Air) & $15,78^{\mathrm{b}}$ \\
K3 (15 cc/L Air) & $16,39^{\mathrm{b}}$ \\
K4 (20 cc/L Air) & $16,28^{\mathrm{b}}$ \\
K5 (25 cc/L Air) & $19,06^{\mathrm{a}}$ \\
\hline
\end{tabular}

$\begin{array}{lllll}\text { Duncan } 0,05: 2,11 & 2,21 & 2,28 & 2,33 & 2,37\end{array}$

Keterangan: Angka-angka yang diikuti huruf yang sama, tidak berbeda nyata pada taraf uji beda Duncan 0,05.

Berdasarkan hasil uji beda duncan 0,05 pada tabel 6 menghasilkan nilai rata-rata parameter berat segar akar 
selada merah terberat jatuh pada perlakuan M2 dengan berat $17,92 \mathrm{~g}$ dan berbeda sangat nyata dengan Perlakuan lainnya, Pada perlakuan M3 yang merupakan perlakuan dengan berat kedua dengan berat $16,19 \mathrm{~g}$ dan tidak berbeda nyata dengan perlakuan M1 yang merupakan perlakuan dengan berat terandah yaitu 14,86 g, Pada parameter ini terdapat peningkatan berat akar terhadap pemberian media tanam dengan presentase sebasar $20,59 \%$.

Tabel 6. Rata-rata pengaruh media tanam pada parameter berat segar akar $(\mathrm{g})$

\begin{tabular}{cc}
\hline Perlakuan & Rata-Rata \\
\hline M1 (Perbandingan 3 Tanah / 1 PKA) & $14,86^{\mathrm{b}}$ \\
M2 (Perbandingan 4 Tanah / 1 PKA) & $17,92^{\mathrm{a}}$ \\
M3 (Perbandingan 5 Tanah / 1 PKA) & $16,19^{\mathrm{b}}$ \\
\hline
\end{tabular}

Duncan 0,05 : 1,49, 1,57

Keterangan: Angka-angka yang diikuti huruf yang sama, tidak berbeda nyata pada taraf uji beda Duncan 0,05 .

Berdasarkan hasil analisis regresi memperlihatkan adanya hubungan linear positif antara berat segar akar dengan pemberian pupuk organik cair dimana permberian pupuk organik cair memberikan perubahan terhadap berat segar akar dengan persamaan $\mathrm{Y}=0,669 \mathrm{x}$ $+13,98$ dan koefisien diterminasinya $\left(\mathrm{R}^{2}=0,759\right) 75 \%$, Dari Gambar 5 tersebut juga dapat dijelaskan bahwa diduga akan cenderung ada peningkatan berat segar akar jika ada penambahan perlakuan dosis pupuk organik cair.

Berdasarkan hasil analisis regresi dapat dilihat bahwa hubungan berat segar akar dengan media tanam membentuk hubungan linear positif dengan persamaan $\mathrm{Y}$ $=0,665 \mathrm{x}+14,99$ dengan nilai $\mathrm{R}^{2}=0,187(18 \%)$ dimana hubungannya mengalami peningkatan berat segar sampai pada M2 dan berlahan cenderung turun pada M3, Dengan demikian media tanam cenderung memberikan hasil yang lebih baik terhadap berat segar akar pada perlakuan M1 dan M2 jika dibanding dengan M3. Hal ini dapat diduga bahwa jika ada penambahan perlakuan media tanam maka berat segar akar tanaman selada merah akan cenderung turun.

\section{Rasio Tajuk Akar (\%)}

Hasil analisis statistik pada tabel 7 menunjukkan media tanam (M) berpengaruh sangat nyata terhadap parameter rasio tajuk akar selada merah pada umur 6 minggu setelah tanam (MST).

Berdasarkan hasil uji beda duncan 0,05 pada tabel 7 menghasilkan nilai rata-rata parameter rasio tajuk akar selada merah tertinggi jatuh pada perlakuan M1 dengan rasio $10,17 \%$ dan berbeda sangat nyata dengan perlakuan lainnya. Pada perlakuan M3 memiliki rasio tertinggi kedua dengan nilai rasio 9,25\% dan tidak berbeda nyata dengan perlakuan M1 yang merupakan perlakuan dengan nilai rasio paling rendah yaitu 8,78\%. Hasil peningkatan rasio tajuk akar terhadap pemberian media tanam dengan presentasenya sebasar $15,83 \%$.

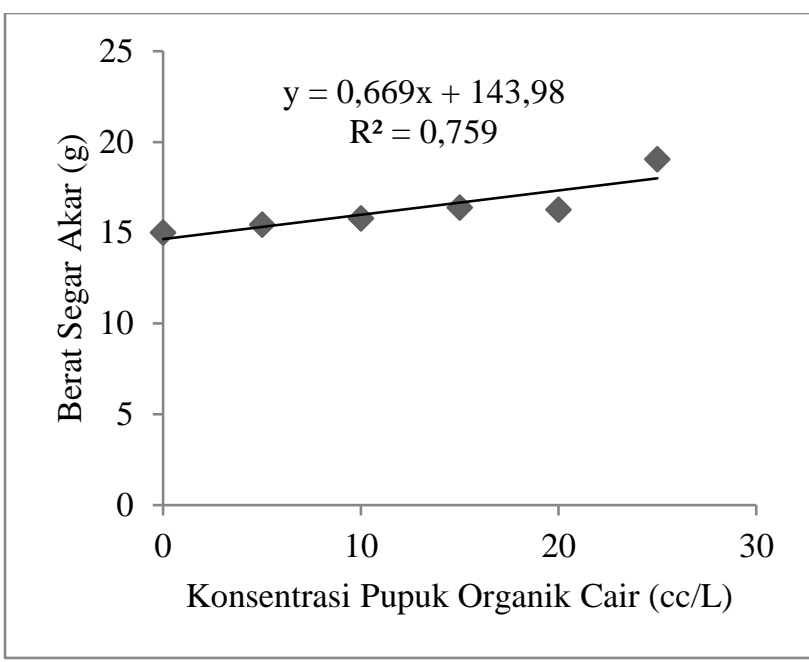

Gambar 5. Grafik analisis regresi rata-rata nilai konsentrasi pupuk organik cair (K) pada parameter berat segar akar selada merah

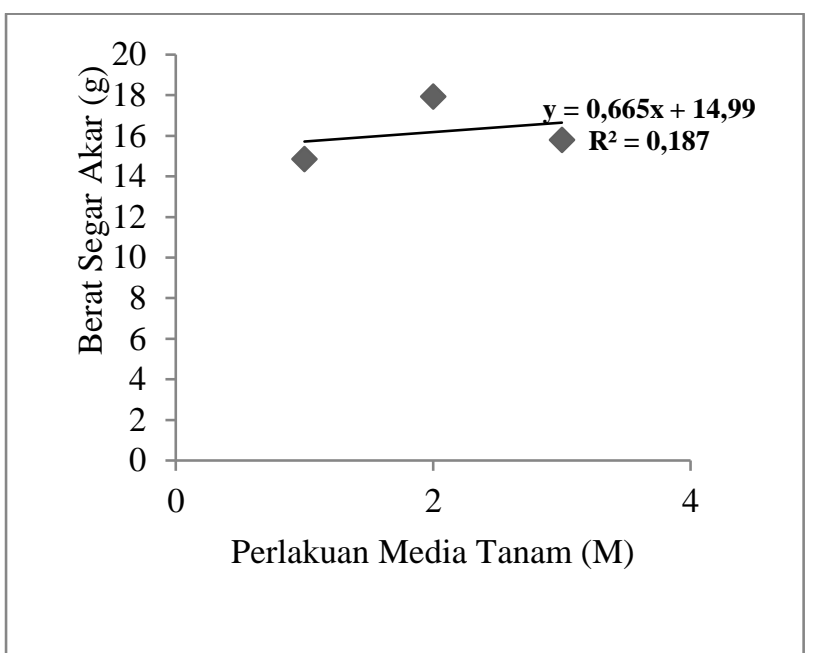

Gambar 6. Grafik analisis regresi rata-rata nilai pengaruh media tanam (M) pada parameter berat segar akar selada merah

Tabel 7. Rata-rata pengaruh media tanam pada parameter rasio tajuk akar (\%),

\begin{tabular}{lc}
\hline Perlakuan & Rata-Rata \\
\hline M1 (Perbandingan 3 Tanah / 1 PKA) & $10,17^{\mathrm{a}}$ \\
M2 (Perbandingan 4 Tanah / 1 PKA) & $8,78^{\mathrm{b}}$ \\
M3 (Perbandingan 5 Tanah / 1 PKA) & $9,25^{\mathrm{b}}$ \\
\hline Duncan 0,05 : 1,61 1,64
\end{tabular}

Duncan 0,05: 1,61 1,64

Keterangan: Angka-angka yang diikuti huruf yang sama, tidak berbeda nyata pada taraf uji beda Duncan 0,05 .

Berdasarkan hasil analisis regresi dapat dilihat bahwa hubungan rasio tajuk akar dengan media tanam membentuk hubungan linear negatif dengan persamaan $Y=-0,46 x+10,32$ dengan nilai koefisiensi determinasi $\left(\mathrm{R}^{2}=0,423\right) 42 \%$. Hal ini menunjukan bahwa rasio tajuk akar meningkat pada titik optimum yaitu M1, dan pada perlakuan M2 dan perlakuan M3 cenderung menurun. Dengan demikian perlakuan M1 cenderung memberikan hasil yang lebih baik dibandingkan dengan perlakuan M2 
dan M3, Dan berdasarkan Gambar 7 juga dapat diduga bahwa jika ada penambahan perlakuan media tanam maka rasio tajuk akar tanaman selada merah akan cenderung menurun.

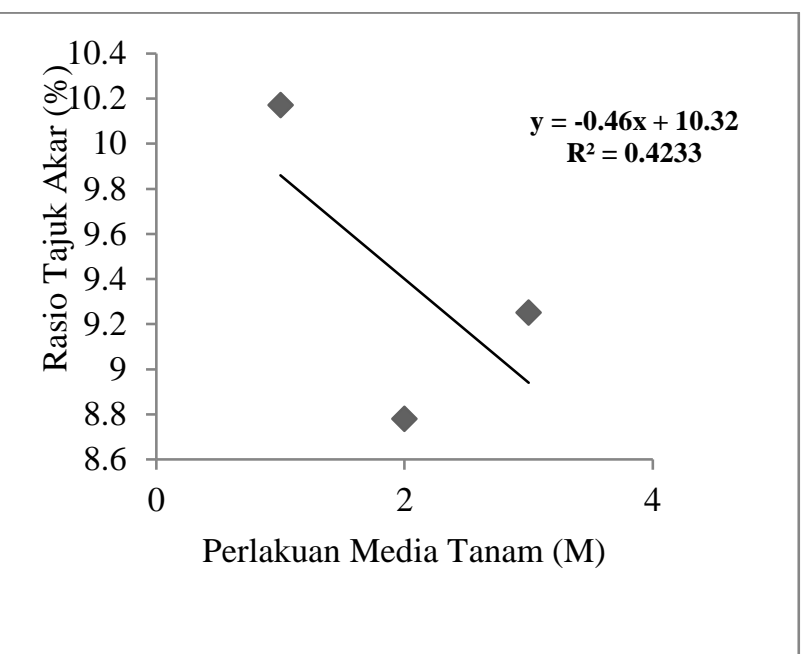

Gambar 7. Grafik analisis regresi rata-rata pengaruh media tanam (M) pada parameter rasio tajuk akar selada merah

\section{Indeks Panen (\%)}

Hasil analisis keragaman pada tabel 8 menunjukan media tanam $(\mathrm{M})$ berpengaruh sangat nyata terhadap parameter indeks panen selada merah pada umur 6 minggu setelah tanam (MST).

Berdasarkan hasil uji beda duncan 0,05 pada tabel 8 menghasilkan nilai rata-rata parameter indeks panen selada merah tertinggi dihasilkan oleh perlakuan M1 dengan indeks $0,91 \%$ dan berbeda sangat nyata dengan perlakuan M3 dan M2. Pada perlakuan M3 merupakan perlakuan dengan indeks tertinggi kedua dengan indeks $0,90 \%$ dan tidak berbeda nyata dengan perlakuan M2 yang merupakan perlakuan dengan indeks terendah 0,90 $\%$. Peningkatan indeks panen terhadap pemberian media tanam dengan presentasenya sebasar $1,11 \%$.

Berdasarkan hasil analisis regresi dapat dilihat bahwa hubungan indeks panen dengan media tanam membentuk hubungan linear negatif dengan persamaan $\mathrm{Y}=-0,005 \mathrm{x}+0,913$ dengan nilai koefisiensi determinasi $\left(\mathrm{R}^{2}=0,75\right) 75 \%$. Hal ini juga menunjukan bahwa indeks panen meningkat pada titik optimum yaitu M1, dan pada perlakuan M2 dan perlakuan M3 cenderung menurun. Dengan demikian perlakuan M1 cenderung memberikan hasil yang lebih baik dibandingkan dengan perlakuan M2 dan M3, Dan berdasarkan Gambar 8 juga dapat diduga bahwa jika ada penambahan perlakuan media tanam maka indeks panen pada tanaman selada merah akan cenderung turun.

\section{Pembahasan}

Berdasarkan hasil penelitian dapat lihat bahwa tanaman selada merah memberikan respons yang berbeda terhadap pemberian konsentrasi pupuk organik cair $(\mathrm{K})$ diantaranya adalah parameter tinggi tanaman, jumlah daun, luas daun, berat segar tajuk dan berat segar akar, Ketersedian nitrogen $(\mathrm{N})$ pada pupuk organik cair dapat memacu peningkatan tinggi tanaman, jumlah daun, luas daun, berat segar tajuk dan berat segar akar pada tanaman selada merah, Sedangkan unsur phosfor $(\mathrm{P})$ pada pupuk organik cair dimanfaat oleh tanaman dalam pembentukan akar sebagai bahan baku pembentukan akar tertentu, pembetukan asimilat dan pernapasan tanaman juga membenatu proses pembentukan daun.

Lain halnya dengan unsur kalium $(\mathrm{K})$ pada pupuk organik cair berperan sebagai metabolisme, karbohidrat, sintesa protein dan memacu kegiatan unsur mineral, Phosfor dan Kalium memiliki peranan penting dalam proses metabolisme tanaman, Phosfor meyebabkan metabolisme berjalan baik dan lancar yang mengakibatkan pembelahan sel, pembesaran sel, dan diferensiasi sel, berjalan lancar, Begitu juga Kalium berperan sebagai aktifator dari berbagai enzim yang penting dalam reaksi fotosintesis dan respirasi, sehingga dapat mengatur serta memelihara potensial osmotik dan pengambilan air yang mempunyai pengaruh positif terhadap penutupan dan pembuksan stomata (Gardner et al, 1991), Hasil penelitian juga menunjukan bahwa media tanam (M) yang merupakan kombinasi pupuk kandang ayam dan tanah ini juga memberikan respons yang sangat baik terhadap berberapa parameter yaitu berat segar akar, rasio tajuk akar dan indeks panen pada tanaman selada merah, Hal ini disebabkan pupuk kandang ayam pada media tanam baik untuk pemupukan karena banyak mengandung zat makanan bagi tanaman, hal ini karena susunan makanan yang banyak mengandung protein, Pupuk kandang ayam pada media tanam mengandung hara makro $\mathrm{N}, \mathrm{P}$ dan $\mathrm{K}$ dan mengandung hara makro yang cukup dan sangat diperlukan oleh tanaman.

\section{Konsentrasi Pupuk Organik Cair}

Berdasarkan hasil analisis keragaman menunjukan konsentrasi pupuk organik cair (K) memperlihatkan bahwa perlakuan K5 (Konsentrasi POC Bioliz $25 \mathrm{cc} / \mathrm{L}$ Air) pada parameter tinggi tanaman $(\mathrm{cm})$, jumlah daun (helai), luas daun $\left(\mathrm{cm}^{2}\right)$ Berat Segar Tajuk (g) dan berat Segar Akar (g) memberikan hasil tertinggi pada tanaman selada merah diikuti oleh perlakuan lainnya seperti K4 (Konsentrasi POC Bioliz $20 \mathrm{cc} / \mathrm{L}$ Air), K3 (Konsentrasi POC Bioliz $15 \mathrm{cc} / \mathrm{L}$ Air), K2 (Konsentrasi POC Bioliz $10 \mathrm{cc} / \mathrm{L}$ Air), K1 (Konsentrasi POC Bioliz $5 \mathrm{cc} / \mathrm{L}$ Air) dan yang paling rendah dari parameter-parameter diatas ditepati oleh K0 (Tanpa Pemberian POC Bioliz). Dari hasil diatas dapat dijelaskan bahwa konsentrasi pupuk organik cair memberikan pengaruh terutama pada perlakuan K5 yang merupakan hasil tertinggi karena konsentrasi pupuk organik mampu memberikan unsur hara yang dibutuhkan untuk pertumbuhan vegetatif tanaman selada merah. Pertumbuhan vegetatif pada tanaman selada sangat berhubungan dengan ketersediaan nitrogen yang 
dikandung oleh pupuk organik cair. Menurut Poerwowidodo (1992) bahwa nitrogen yang terkandung didalam pupuk organik cair berperan sebagai penyususn protein. Hal ini juga didukung oleh pendapat Sutedjo (1994), mengatakan bahwa unsur nitrogen $(\mathrm{N})$ berperan penting dalam merangsang pertumbuhan vegetatif tanaman seperti tinggi tanaman jumlah daun dan perpanjangan akar. Lingga (2002) mengemukakan bahwa peran unsur hara nitrogen yang terdapat dalam pupuk organik cair berfungsi merangsang tanaman secara keseluruhan khususnya cabang, batang, daun, Nitrogen juga berperan penting dalam pembentukan hijau daun untuk fotosintensis. Menurut Mandala (2008), nitrogen bagi tanaman mempunyai peran untuk merangsang pertumbuhan tanaman secara keseluruhan, khususnya cabang batang dan daun.

Pupuk organik cair juga mengandung unsur hara makro dan mikro dimana ketersediaannya dapat meningkatkan pertumbuhan dan produksi tanaman selada merah merah. Poerwowidodo (1992), mengatakan bahwa unsur hara makro dan unsur hara mikro yang terkandung dalam pupuk organik cair menghasilkan pengaruh yang kompleks terhadap pembentukan dan produksi karbohidrat.

Tabel 8. Rata-rata pengaruh media tanam pada parameter indeks panen (\%)

\begin{tabular}{|c|c|}
\hline Perlakuan & Rata-Rata \\
\hline M1 (Perbandingan 3 Tanah / 1 PKA) & $0,91^{\mathrm{a}}$ \\
\hline M2 (Perbandingan 4 Tanah / 1 PKA) & $0,90^{b}$ \\
\hline M3 (Perbandingan 5 Tanah / 1 PKA) & $0,90^{\mathrm{b}}$ \\
\hline
\end{tabular}

Duncan 0,05 : 0,0065 0,0068

Keterangan: Angka-angka yang diikuti huruf yang sama, tidak berbeda nyata pada taraf uji beda Duncan 0,05 .

\section{Media Tanam (M)}

Hasil analisis keragaman juga didapati media tanam yang merupakan kombinasi antara tanah dan pupuk kandang ayam dengan perbandingan tertuntu memberikan respons yang terbaik pada tiga parameter dan memiliki nilai rara-rata teringgi yaitu berat segar tajuk akar pelakuan M2 (17,92 g) diikuti dengan perlakuan M3 (16,19 g) dan tidak berbeda dengan M1 $(14,86 \mathrm{~g})$ yang merupakan hasil terendah dari parameter tersebut. Rasio tajuk akar perlakuan M1 (10,17 \%) merupakan yang tertinggi dan berbeda dengan perlakuan lainnya diikutiti perlakuan M3 $(9,25 \%)$ yang tidak berbeda nyata dengan M2 $(8,78 \%)$ yang merupakan hasil terendah. Indeks panen dengan nilai tertinggi terdapat pada perlakuan M1 $(0,91 \%)$ diikuti juga oleh perlakuan M3 $(0,90 \%)$ dan tidak berbeda nyata dengan M2 (0,90 \%) yang merupakan hasil terendah dari parameter tersebut. Dari hasil diatas dapat dijelaskan bahwa pemberian media tanam yang tepat juga dapat memberikan hasil yang optimal bagi pertumbuhan dan produksi tanaman selada merah. Selain itu pertumbuhan tanaman selada juga tidak terlepas dari lingkungan tumbuh seperti cahaya, suhu dan sebagainya yang mempengaruhi hasil tanaman

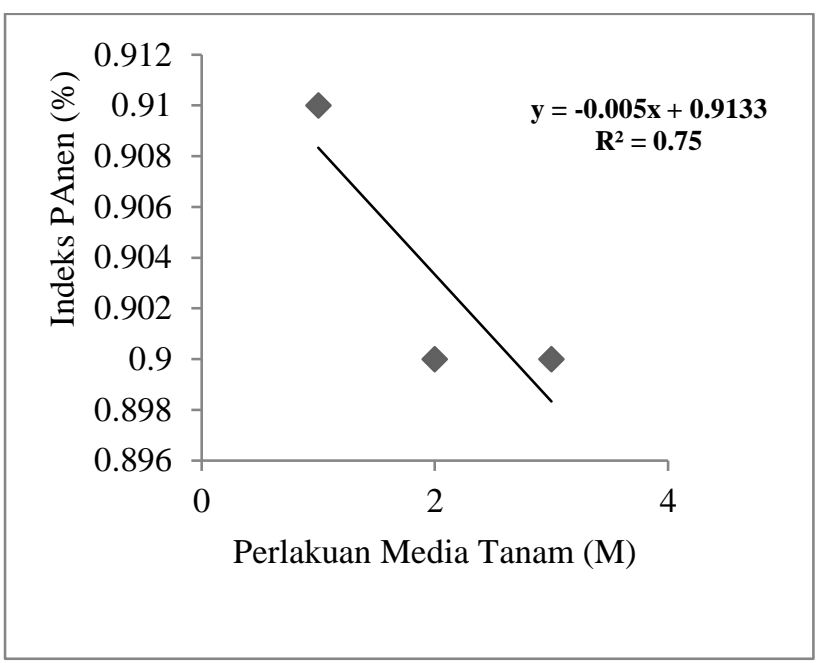

Gambar 8. Grafik analisis regresi rata-rata nilai pengaruh media tanam (M) pada parameter indeks panen selada merah,

Pada parameter berat tajuk akar dengan adanya ketersediaan unsur hara dari media tanam dan air dapat menunjang proses pemanjangan akar dalam tanah yang merupakan salah satu usaha tanaman untuk memenuhi kebutuhannya. Hal ini juga disebabkan karena pemberian media tanam yang baik dapat terpenuhinya kebutuhan tanaman akan unsur hara dan dengan tersedianya $\mathrm{N}, \mathrm{P}$ dan $\mathrm{K}$ pada media yang mencukupi untuk pertumbuhan tanaman terutama pada akar. Perkembangan sistem percabangan akar akan lebih lebih teransang pada media tanam dimana air dan unsur hara lebih tersedia, Berat tajuk akar merupakan faktor penting dalam pertumbuhan tanaman yang mencerminkan kemampuan penyerapan unsur hara serta metabolisme yang terjadi pada tanaman. Lakitan (2007) menyatakan sebagian besar unsur yang dibutuhkan tanaman diserap dari larutan tanah melalui akar.

Pada parameter rasio tajuk akar merupakan perbandinagan antara berat segar tajuk dan berat segar akar pada tanaman selada, Media tanam bersifat sangat porous sehingga mampu menyediakan udara yang banyak bagi pertumbuhan akar dengan demikian akar tumbuh cepat dan mampu menyerap nutrisi maksimal untuk pertumbuhan tajuk. Perbandingan tajuk akar mempunyai pengertian bahwa pertumbuhan suatu tanaman diikuti dengan pertumbuhan bagian tanaman lainya, dimana tajuk akan meningkat secara ratio tajuk akar mengikuti peningkatan berat akar (Gardner et al.,1991). Jumin (2002) menyatakan bahwa pesatnya pertumbuhan vegetatif tanaman tidak terlepas dari ketersediaan unsur hara di dalam tanah. Ketersediaan unsur hara akan menentukan produksi berat kering tanaman yang merupakan hasil dari tiga proses yaitu proses penumpukan asimilat melalui proses fotosintesis, respirasi dan akumulasi senyawa orgnik.

Sementara pada parameter indeks panen menyangkut pertumbuhan pucuk dan akar, Pertumbuhan 
kedua organ tersebut sangat kompleks terutama pada hal mobilisasi fotosintat itu banyak faktor yang mempengaruhi tanaman, apabila keadaan terbatas maka pertumbuhan akar akan digalakkan untuk mendapatkan hara dan air yang lebih banyak. Gardner et al. (1991) manyatakan bahwa pada keadaan stres air, tanaman akan membentuk pertumbuhan akar yang lebih besar dibandingkan apabila tanaman tidak mengalami kekeringan. Indeks panen juga menyangkut kemampuan tanaman selada merah dalam menyalurkan asimilat. Laju asimilasi merupakan ukuran rata-rata efesiensi fotosintesis daun pada tanaman selada merah. Nilai laju asimilasi akan semakin menurun ditandai dengan semakin bertambahnya umur tanaman, karena semakin meningkatnya indeks luas daun maka semakin banyak yang ternaungi. Hal ini menyebabkan penurunan laju asimilasi selama masa pertumbuhan tanaman selada merah (Gardner et al., 1991).

\section{Analisis Regresi}

Konsentrasi optimum pupuk organik cair (K) untuk parameter tinggi tanaman, jumlah daun, luas daun, berat segar akar tajuk dan berat segar akar adalah K5 karena pada konsentrasi tersebut mampu meningkatkan tinggi tanaman, jumlah daun, luas daun, berat segar akar tajuk dan berat segar akar dan merupakan konsentrasi terbaik untuk kelima parameter tersebut.

Sedangkan untuk media tanam (M) parameter berat segar akar dosis optimumnya adalah pada perlakuan M2 dan pada parameter rasio tajuk dan indeks panen dosis optimum adalah M1. Dosis media tanam yang lebih tinggi M3 tidak mampu maningkatkan barat segar akar, rasio tajuk akar dan indeks panen, Pada perlakuan M1 dianggap mampu meningkatkan kekurangan hara dan mampu memperbaiki kondisi fisik tanah menjadi yang lebih baik sehingga kebutuhan unsur hara dapat terpenuhi.

Konsentrasi pupuk organik cair tidak mampu meningkatkan berat segar tajuk perlakuan K4 sedangkan pada media tanam juga tidak mampu meningkatkan berat segar akar pada perlakuan M3, parameter rasio tajuk akar pada perlakuan M2 dan indeks panen juga pada perlakuan M2. Hal ini disebabkan karena faktor genetik dari tanaman selada merah lebih dominan dibandingkan faktor lingkungannya dalam memacu pertumbuhan tinggi tanaman, berat segar tajuk dan berat segar akar, rasio tajuk dan indeks (Surtinah, 2009).

\section{KESIMPULAN}

Berdasarkan hasil penelitian yang diperoleh maka dapat disimpulkan diantaranya sebagai berikut:

1. Konsentrasi pupuk organik cair $(\mathrm{K})$ memberikan pengaruh sangat nyata terhadap terhadap parameter tinggi tanaman, jumlah daun, luas daun dan memberikan pengaruh sangat nyata juga pada parameter berat segar tajuk dan berat segar akar, Media tanam (M) memberikan pengaruh sangat nyata terhadap parameter berat segar akar, rasio tajuk akar dan parameter indeks panen serta Interaksi pupuk organik cair $(\mathrm{K})$ dan media tanam (M) tidak memberikan pengaruh nyata pada semua parameter.

2. Pada konsentrasi pupuk organik cair (K) memberikan presentase pertumbuhan tanaman pada parameter tinggi tanaman $(43,78 \%)$, jumlah daun $(36,16 \%)$, luas daun $(42,52 \%)$, berat segar tajuk $(18,11 \%)$ dan berat segar akar $(27,07 \%)$ serta Pada media tanam (M) memberikan presentase pertumbuhan tanaman selada merah untuk parameter berat segar akar (20,59\%), Rasio tajuk akar $(15,83 \%)$ dan indeks panen $(1,11 \%)$.

3. Dari hasil analisis regresi dapat diduga bahwa dengan adanya penambahan perlakuan pupuk organik cair (K) masih dapat meningkatkan produktivitas tanaman selada, Sadangkan pada media tanam (M) dapat diduga dengan adanya penambahan perlakuan maka produktivitas tanaman selada merah akan cenderung menurun.

\section{DAFTAR PUSTAKA}

Gardner, F.P., R.B. Pearce, dan R.L. Mitchell. 1991. Physiologicy of Crop Plants. Terjemahan Herawati Susilo. Fisiologi Tanaman Budidaya. Universitas Indonesia Press 428p.

Indrakusuma. 2000. Proposal Pupuk Organik Cair Supra Alam Lestari. PT Surya Pratama Alam. Yogyakarta.

Jumin, H.B. 2002. Dasar-Dasar Agronomi. Rajawali. Jakarta.

Kaya, E. dan A. Siregar. 2016. Penelitian Pembuatan Pupuk Organik Cair dan pupuk Kompos. Fakultas Pertanian. Universitas Pattimura. Ambon.

Lakitan, B. 2007. Fisiologi Pertumbuhan dan Perkembangan Tanaman. Raja Grafindo Persada. Jakarta.

Lingga, P. 2002. Petunjuk Menggunakan Pupuk. Penebar Swadaya. Jakarta.

Luhukay, M. 2017. Klasfikasi Tanah Desa Poka. Fakultas Pertanian. Universitas Pattimura.

Mandala. M. 2008. Morfologi perakaran tanaman Kedelai (Glycine max) sebagai pengaruh diameter kelereng atau agregat tanah. Agritrop 6: 107-112.

Musnamar. 2003. Pupuk Organik Cair dan Padat. Pembentukan dan Aplikasi. Penebar Swadaya. Jakarta.

Poerwowidodo. 1992. Telaah Kesuburan Tanah. Penerbit Angkasa, Bandung. dalam Parman, S. 2007. Pengaruh pemberian pupuk organik cair terhadap pertumbuhan dan produksi kentang (Solanum tuberosum L.). Buletin Anatomi dan Fisiologis 15: 21-31.

Rizqiani, N., F.A. Erlina, dan W.Y. Nasih. 2007. Pengaruh dosis dan frekuensi pemberian pupuk organik cair terhadap pertumbuhan dan hasil buncis. Jurnal Ilmu Tanah dan Lingkungan 7: 4345. 
Sa'diah. H. 2015. Pengaruh Pemberian Pupuk Organik Cair Urin Kelinci pada Tanaman Selada Merah (Lactucasativa L.). Politeknik Pertanian Negeri Bayakumbah. Laporan Akhir. Tahun 2015.

Sitompul. S.M. dan Guritno. 1995. Analisis Pertumbuhan Tanaman. UGM-Press. Yogyakarta. Hal : 165-200.

Surtinah. 2009. Pemberian pupuk organik Super Natural Nutrition (SNN) pada tanaman selada (Lactuca sativa L) di tanah ultisol. Jurnal Ilmiah Pertanian 6: 1-9.

Sutedjo. 1994. Pupuk dan Pemupukan. Penerbit Rineka Cipta. Jakarta.

Widarto, L. 1996. Perbanyakan Tanaman Dengan Biji. stek. Cangkok. Sambung. Okulasi dan Kultur Jaringan. Kanisius. Yogyakarta. 130p. 